\title{
A Critical Discourse Analysis of Gaza Marches of Return Coverage in Selected Newspapers
}

\author{
Yakoub Abu Taha \\ Faculty of Foreign Languages, University of Jordan \\ Jordan \\ E-mail: jacajori@Gmail.com \\ Rajai Al-Khanji \\ Faculty of Foreign Languages, University of Jordan \\ Jordan
}

Received: August 2, 2020 Accepted: December 20, 2020 Published: December 27, 2020

doi:10.5296/ijl.v12i6.17959

URL: https://doi.org/10.5296/ijl.v12i6.17959

\begin{abstract}
The current study aimed at discovering biases through comparing the used journalistic and lexicalizations practices in quotations patterns and representations of social actors in news coverage of the Gaza Marches of Return. The selected newspapers were The Guardian, the New York Times, The Jordan Times and Haaretz. The study sample comprised 32 news articles and 8 editorials. The findings of the study revealed that more space was given to Israeli political and military actors over their Palestinian counterparts in the New York Times and Haaretz. The Guardian and the Jordan Times quotations of Palestinian civilian actors focused on human suffering and casualties themes while Haaretz and the NYT quoted them instigating deadly attacks among other themes. The use of negative themes along with negative speakers' descriptions of Palestinian political actors revealed biased stances against Palestinian Civilian Actors. In addition, the used reporting verbs, unbalanced quotations distributions and word counts of social actors' quotations pointed at biased practices and adoption of one party narrative in the case of the NYT, Haaretz and the Jordan Times.
\end{abstract}

Keywords: CDA, Quotation patterns, Ideology, News bias, Gaza marches of return 


\section{Introduction}

News reporting is a profession governed by truthfulness, integrity, balance, and accuracy. Nevertheless, news is found to be presented differently to suit its audience as it can be wrapped by layers of Syntax and Semantics in its Discourse. This is evident when the same piece of information is presented differently when reported by one given news agency to another. Consequently, events are viewed differently by the news agencies reporting them, each according to their agendas (Zelizer, Park and Gudelunas, 2002; van Dijk, 2018). There is an increasing recognition of media importance and potential in covering conflicts (UNDP 2017). It has gathered scholars to study its role of the social life recently, especially with the introduction of innovative digital life style (Mihelj and Stayner 2018:4).

The case of the Israeli-Palestinian conflict proves itself as an example of how ideology and political agendas play a role in the way news reporting is presented. Newspapers have been accused of bias because of their nationality, religion and political views among others. News reporting, In this case, contradicts with White's (2000:379) news criteria, namely objectivity, accuracy and neutrality by adopting journalists' assertions. This study aims to contribute to the critical discourse library on the discourse of conflict.

Since March 30th 2018, a series of Gaza Marches of Return have emerged as a way to draw attention to the Palestinian cause. The demonstrations that sought some popular demands were confronted with Israeli army excessive force. At least 110 Palestinian protestors were killed and thousands injured only in the first month of protests by Israeli soldiers (Sanchez and Oliphant, 2018; Morris and Balousha, 2018). Reporting the events of the Gaza Marches of return by different newspapers will produce varying news accounts, each according to their agendas, ideologies, and political views. Unbalanced representations of Palestinians and Israelis social actors can be shown in textual analysis and quotation patterns.

\subsection{Question of the Study}

The study aims to answer the following question:

1) How are the quotation patterns of social actors and their sourcing technique used by the selected newspapers in reporting the Gaza Marches of Return?

2) How biased are the journalistic and lexicalization practices when quoting the social actors in the selected newspapers?

\subsection{Significance of the Study}

Unlike recent research that analyzed the two intifadas or Gaza wars, the study addresses the Gaza Marches of Return news discourse for the first time up to our knowledge. These marches were faced with sever measures by the Israeli forces. Moreover, the Marches of Return have not yet been investigated within a CDA approach to the best of the researcher's knowledge. Moreover, the study gains importance because it will try to compare and highlight the journalistic features among The New York Times (NYT), The Guardian (GU), Haaretz (HZ) and The Jordan Times (JT). 


\section{Review of Literature}

CDA adopts no specific approach, theory, or method to be performed (van Dijk, 1995:1) (Blackledge, 2005: 13). Researchers in the field apply numerous approaches that have common primary theoretical basis and assumptions. The CDA's approaches can be referred to well-known pioneers in the field such as: Norman Fairclough, Ruth Wodak and Teun van Dijk and other scholars. CDA is an interdisciplinary approach because it draws on different disciplines, Ex. Linguistics, Sociology, Politics, Sociolinguistics, Media, and Psychology. And it was a method it has been employed by researchers of such fields accordingly. CDA is a modern approach; hence it gets improvements by researchers' inputs in the field and upon usage in other fields (Titscher and Jenner 2000: 78).

The CDA presentation of the discourse and society linkage avoids simplicity; it rather studies implied power used in discourse within a particular context. As a beginning, it assumes that powerful groups tend to normalize their discourse so that their dominant ideology seems like 'given information' or 'taken for granted'. Resisting a given dominant ideology entails questioning those existing beliefs and conventions and trying to have them changed. In the study of how conventional and creative language is used, it is imperative that CDA analysts examine the given discourse in context and to analyze the 'intertextual' as well as its 'interdiscursive' properties. The CDA theorists regard discourse as historical. They argue that, without knowledge of its context, it may not be analyzed or understood (Wodak, 1996).

\subsection{Studies on Israeli-Palestinian Conflict Reporting}

Zelizer, Park \& Gudelunas (2002) study focused on gather any anti-Israeli trends Palestinian Uprising 'Intifada' coverage in the USA, The NYT, The Washington Post and the Chicago Tribune. They concluded that all newspapers are conservative in handling the details of Israeli army treatment of Arabs, and that bias in such human issue is inevitable due to nature of the topic.

Dunsky (2008) conducted a study on US journalistic practices in reporting the Palestinian Israeli conflict in American mainstream media. Dunsky's analyses of the news reports by twelve news outlets pointed out that they lack necessary contextualization, American role, international law and relevant agreements to the conflict. She also linked news reporting to US Foreign policy as well as providing empirical evidence of pro-Israeli news reporting bias in the American media on the Arab Israeli conflict.

Philo \& Berry (2004 \& 2009) Analyzed the media coverage of the Israeli war against Gaza in 2008. They have come to the fact that the BBC and ITV have failed to provide fair and balanced coverage of the conflict. Both of the conducted studies helped shed some light on the biases performed by UK media, but they have confined themselves to the television news network leaving behind newspapers and other digital information technology news outlets.

Bazzi (2009) studied the Israeli Palestinian conflict from the Arab media perspective for the period 2001- 2009, it focused on Ideologies, power relations, cognition and editorial control provide solid grounds for the final semantic, structural and pragmatic choices in news texts. It found a systematic pattern in Arab news outlets that are based on their ideological stances. 
Deprez \& Raeymaeckers (2011) studied the representation of Israelis and Palestinians in the news coverage of the first and second intifada by the Flemish press. They found that the portrayal of the Palestinian actors shifted from a rather positive view during the first intifada period to a more critical portrayal during the period of the second intifada. Some newspapers favored the Israeli side by (the use of sources) while others opted the Palestinian side in (Ex. the individualization of victims).

Segev and Miesch (2011), in their media study, analyzed the corpus of 14 large newspapers in five countries - the UK, France, Germany, Italy, and Switzerland. They found that the UK newspapers are the most critical and negative toward Israel, while Italian news the most supportive. German, French and Swiss news were relatively more neutral. They proposed that the Opinions presented in the news are not in line with public opinion as presented in annual surveys of each country.

Amer (2015) analyzed the Israeli war on Gaza in 2008 by The Guardian, The Times London, The NYT and The Washington Post. His Findings indicated that the most quoted and mentioned social actors in the 2008 Israeli war on Gaza are the Israeli politicians then the Palestinian civilians. Transitivity analysis showed similarities among the four newspapers in representing the social actors, Ex. they foreground Israeli agency in achieving a ceasefire and targeting Hamas and foreground Hamas rejection of a ceasefire.

Qawariq (2016) analyzed Palestinian news websites and Israeli newspapers online versions on the 2014 Gaza war. The results of his study revealed marginal ideologies in Israel that competed with a hegemonic Zionist discourse. The study also showed that Palestinian news websites subtly exploited representations of events and social actors in their struggle for power and legitimacy.

Farrah (2018) studied the Israeli-Palestinian conflict in a newspaper heading analysis. His data showed four key notions: the peace process the occupation, terrorism, and settlements. Farrah focused on Grammatical and lexical metaphor euphemism and stereotypes in his study.

In summary, while covering news discourse studies of the two (popular uprisings) Intifadas and both Gaza Wars, some researchers conducted their Palestinian/ Israeli conflict studies based on western news media like (Farrah 2018) (Segev and Miesch 2011, media study) (Amer 2015) (Zaher, 2009) and (Qawariq, 2016), or like Bazzi (2009) who confined her research to Arabic discourses. This study however adopts a comparative analysis of news discourse from The NYT, The GU, HZ and The JT. The reason for selecting The JT is that it is the closest well established English speaking newspaper to the Palestinian cause regardless of the Palestinian political factions on the ground.

The current study employs CDA framework to analyze the quotations distributions of each group in each newspaper to find any quantitative biases. The analysis will go further to discuss the reporting expressions used to describe those actors and the reporting expressions for their quotes. This aids to discover the images of each social actors group that newspaper represented while covering the Gaza Marches of Return. The news coverage of these protests, 
to this date, has not yet been discussed by any linguistic nor media studies to the best of my knowledge.

\section{Methodology}

\subsection{The Newspapers}

The Guardian (GU) is a British daily newspaper owned by the Scott Trust that was founded in 1821 under the name The Manchester Guardian (Bold 2018). It was changed to its current name in 1959(the guardian.com). The New York Times (NYT) is a daily US newspaper that was established and published in New York City in 1851(Van Dijk 1998, Riofrancos 2002). The Jordan Times (JT) is an independent English-language daily newspaper published on paper and online. It is created by the Jordan Press Foundation in 1975. Haaretz (HZ) "News of the Land of Israel" that is owned by Schocken family is an Israeli English newspaper. It was founded in 1918 which makes it the longest running printed newspaper in Israel (Center for Research Libraries 2018).

\subsection{Data Collection}

Data collection of the news articles and editorials is confined to the four news media coverage of the Gaza Marches of Return between March 30th 2018 and March 30th 2019. Data will be collected from the newspapers' websites: www.theguardian.com/international, www.nytimes.com, www.Haaretz.com, and www jordantimes.com. The corpus is classified under each newspaper name; each article will be saved separately and dated in word file format for later analysis.

In order to obtain a representative sample from the above newspapers, the study will follow a purposive sampling technique of the data. This method is widely used in qualitative research to insure optimal identification and selection of information cases that yields in effective use of limited resources (Patton, 2002, Amer 2015:69, Seale 2012). The picked sample in the study is based on similarity of the topic then their date of publication to ensure uniformity in order to compare aspects of the news pieces.

The sample of this study is made out of 32 news articles and 8 editorials. The study analyzes the distributions of inclusion and exclusion of social actors, role allocation, genericisation and specification, nomination and categorization, and functionalisation and identification, $E x$. the people, a soldier, a man, "Saleh" or "Jane". Finally, further analysis of quotation patterns and sources used while covering the Gaza Marches of Return are performed. Reporting verbs like said "claimed or stated" among others will be listed, compared and analyzed. This analysis includes frequency distributions and quoting verbs that may reflect ideologies and power relation. The sample of the study follows a purposive sampling procedure of news data that follows a systematic method:

1. The selection of news stories is confined to articles published on the chosen newspapers' website pages that deal with the Gaza Marches of Return \& their implications.

2. The selected news stories must only be between March 30th 2018 and March 30th 2019. 
3. Each article is labeled for word count; aggregated word count of newspaper articles is produced; finally, word averages of each newspaper are calculated.

A total of eight news report and two editorials that fall or approximate the average word count in the nearest two editorials to the average word count will be selected for analysis each newspaper, four of the closest news articles and one editorial above word average are picked and another four with one editorial below average as well. This method insures that the chosen articles fall in the medium range of the discussed topics in the population of the study. In total 40 articles will be analyzed. See table 1.

Table 1. Distributions of newspaper articles

\begin{tabular}{lllll}
\hline & $(\mathrm{GU})$ & $(\mathrm{NYT})$ & $(\mathrm{HZ})$ & $(\mathrm{JT})$ \\
\hline Number of News Stories & 33 & 28 & 36 & 51 \\
\hline Total Word Count & 34143 & 39824 & 31315 & 29471 \\
\hline Average Word Number & 1019 & 1422 & 894 & 577 \\
\hline
\end{tabular}

\subsection{Data Analysis}

The analysis of quotation patterns in this study follows the classification put forward by Richardson (2007:101) who adopts Fairclough's (2003) Intertextuality framework under the heading of internal intertexutality: quotation and reported speech. Intertextuality or emerging discourses across articles happens as the developments in the same story are portrayed over time without including themes, and meaning is more communicated by what is excluded as in fact included (Richardson, 2007). In Richardson's study (2007:101-106), there are five quotation patterns in his model:

1. Direct Quotation refers to "exact words are included in quotation marks, they are put in a reporting clause". That means that what is written between the quotation marks is essentially the exact words of the speakers. The use of direct quotes represents "the news as a fact that is invulnerable to questioning because it is coming from an official, an informed source or a witness. They also help in any reservations by the journalist or the newspaper against what is said.

2. Indirect quotation refers to what "the reporter provides a summary of the content of what was said or written, not the actual words used". In such type, the reporter's voice is presented by how the source writers/speakers are paraphrased.

3. Transformed indirect quotation uses the quotation marks, but do not use reporting phrases with said, claimed, accused, alleged etc. instead they use transitive actions (Ex. discovered, revealed) or mental state verbs (Ex. believes) (examples from Amer 2015:99).

4. Strategic Quotation refers to any "writing or thoughts of people and are placed in quotation marks in order to indicate their contentious nature"

5. Ostensible direct quotation is used when the meaning is taken from the source, but the journalist changed its structure to suit the rhetorical flow of the news piece. The clause 
still entails that the structure direct speech but it is conceptually different from direct quotation through use of invented similar quotations. (Richardson 2007:101-106)

In this study, more focus will be given to the examination of direct and indirect quotations patterns used by the newspapers. As explained by Amer (2015), the direct and indirect quotations are the most common patterns in the news texts while other types are more used in headlines especially the strategic quotation. In addition, there is a difficulty in judging whether the quotation is invented by the newspaper as is the case of ostensible quotations to be "better than the real one" (Richardson, 2007:105).

\section{Analysis}

\subsection{Quotations Distributions}

In the procedures of this analysis, this section analyses the distributions of quotations patterns among the social actors. The general patterns of news sources quotation employed by the newspapers is shown in Table 2 . We can see that The $G U$ assigned more quotations and word count for Israeli groups compared to the Palestinian actors groups, (34.44\%) quotations and word count $(33 \%)$ and assigned $(29.97 \%)$ of its quotations and word count $(31.1 \%)$ to the Palestinian actors. The NYT on the other hand assigned the Palestinian groups more quotations (48\%) compared to Israeli sources (40\%), but when calculating the word count for each group, we find that both groups have almost identical space distributions at around $(42 \%)$ each. This means that even though the Palestinian actors were assigned more quotations in the news coverage of the protests, they still have the same amount of space the Israeli actors have. The $J T$ and $H Z$ quotations pattern for sourcing the social actors are the most radical among the population of the study. The JT assigned (54.17\%) of quotations and word count $(57.69 \%)$ to the Palestinian actors while the Israeli sources were assigned (33.33\%) with word count (28.26\%). $H Z$ assigned (33.33\%) of the quotations and word count $(41.1 \%)$ to the Israeli actors while assigning $(23.81 \%)$ of its quotations and word count $(19.77 \%)$ for the Palestinian side.

Table 2. Total newspapers quotations distributions

\begin{tabular}{|c|c|c|c|c|c|c|c|c|c|c|}
\hline \multirow[b]{2}{*}{ Newspaper } & \multicolumn{4}{|c|}{ Direct Quotations } & \multicolumn{4}{|c|}{ Indirect Quotations } & \multicolumn{2}{|l|}{ Total } \\
\hline & no. & $\%$ & $\begin{array}{l}\text { word } \\
\text { count }\end{array}$ & $\%$ & no. & $\%$ & $\begin{array}{l}\text { word } \\
\text { count }\end{array}$ & $\%$ & quotations & $\begin{array}{l}\text { word } \\
\text { count }\end{array}$ \\
\hline The Guardian & 50 & $55.56 \%$ & 2035 & $61.18 \%$ & 40 & $44.45 \%$ & 1291 & $38.80 \%$ & 90 & 3326 \\
\hline The NYT & 40 & $54.80 \%$ & 1892 & $62.33 \%$ & 33 & $45.21 \%$ & 1141 & $37.58 \%$ & 73 & 3033 \\
\hline The Jordan Times & 15 & $31.24 \%$ & 623 & $38.60 \%$ & 33 & $68.75 \%$ & 991 & $61.41 \%$ & 48 & 1614 \\
\hline Haaretz & 24 & $57.13 \%$ & 1013 & $63.20 \%$ & 18 & $42.85 \%$ & 584 & $36.44 \%$ & 42 & 1597 \\
\hline
\end{tabular}

The overall distribution of quotation patterns in 2 shows that The GU and The NYT have the highest number of quotation patterns with 90 and 73 quotations and the highest word count of quotations with 3326 and 3033 words respectively. According to table 1 we find that western newspapers have more space to discuss their topics and to include sources, as The $G U$ averages ( 1019 words) and The NYT(1422 words). When compared to HZ it has (894 words) and The JT has the least with (577 words). These distributions lead to the understanding that 


\section{MlMacrothink}

International Journal of Linguistics

ISSN 1948-5425

2020, Vol. 12, No. 6

despite the fact that Israel killed civilians at Gaza border, they still enjoy more or equal space to defend themselves in GU and NYT.

The JT and $H Z$ have zero direct quotes for IPA as they are assigned indirect quotations at (12.5\%) for the JT and (2.38\%) for $\mathrm{HZ}$. HZ only official direct quotations come from the Israeli military and (14.29\%) indirect. Among Israeli groups, The GU has the most direct quotation distribution of IMA (10\%), while indirect (6.67\%). The NYT has an equal number of quotation but higher indirect ones, (9.59\%) direct and (12.33\%) indirect. The JT, however, used four times more indirect (16.67\%). The Use of direct quotes provides the adaptation of speakers' opinions, defense or emotions without interference from the journalist (Floyd 2000; Richardson (2007). Hence, the GU, NYT and HZ provide ground for IMA to present their narrative to their readers. The absence of quotes from Palestinian military actors comes natural due to the nature of the protests and the absence of the any militarized activities on the scene despite HZ and NYT narratives.

The distributions of other actors' quotations in $G U$ are the highest among other newspapers with even direct and indirect quotes. The NYT has a tendency towards direct quotations for all actors. The JT has more indirect quotes of other social actors while in $H Z$ quotes were mostly direct quotes $(30.95 \%)$ compared to (14.29\%) indirect quotations. It is worth noting that while JT included mainly UN actors, the NYT has the least sources of other actors. This shows that it relies less on international powers to having their input. When this pattern is compared to the GU, it asserts the inclusion of other voices in GU unlike the NYT although it has extended word limit in its articles. Table 3 provides detailed distributions of all social actors found in the study sample.

Table 3. Detailed distributions of social actors' quotations in the four newspapers

\begin{tabular}{|c|c|c|c|c|c|c|c|c|c|c|c|c|}
\hline \multirow{3}{*}{$\begin{array}{l}\text { The Guardian } \\
\text { Quotation Sources } \\
\text { Israeli political actors }\end{array}$} & \multicolumn{4}{|c|}{ Direct Quotations } & \multicolumn{4}{|c|}{ Indirect Quotations } & \multicolumn{4}{|c|}{ Total } \\
\hline & \multirow{2}{*}{$\frac{\text { no. }}{8}$} & \multirow{2}{*}{$\begin{array}{l}\% \\
8.89 \%\end{array}$} & \multirow{2}{*}{$\begin{array}{l}\text { word } \\
\text { count }\end{array}$} & \multirow{2}{*}{$\frac{\%}{7.52 \%}$} & \multirow{2}{*}{$\frac{\text { no. }}{5}$} & \multirow{2}{*}{$\begin{array}{l}\% \\
5.56 \%\end{array}$} & \multirow{2}{*}{$\begin{array}{l}\text { word } \\
\text { count }\end{array}$} & \multirow{2}{*}{$\frac{\%}{4.18 \%}$} & \multicolumn{2}{|c|}{ quotations } & \multicolumn{2}{|c|}{ word count } \\
\hline & & & & & & & & & 13 & $14.44 \%$ & 389 & $11.70 \%$ \\
\hline Israeli Military actors & 9 & $10.00 \%$ & 344 & $10.34 \%$ & 6 & $6.67 \%$ & 194 & $5.83 \%$ & 15 & $16.67 \%$ & 538 & $16.18 \%$ \\
\hline Israeli civilian actors & 3 & $3.33 \%$ & 171 & $5.14 \%$ & 0 & $0.00 \%$ & 0 & $0.00 \%$ & 3 & $3.33 \%$ & 171 & $5.14 \%$ \\
\hline Palestinian political actors & 5 & $5.56 \%$ & 187 & $5.62 \%$ & 7 & $7.78 \%$ & 195 & $5.86 \%$ & 12 & $13.30 \%$ & 382 & $11.49 \%$ \\
\hline Palestinian military actors & 0 & 0 & 0 & 0 & 0 & 0 & 0 & 0 & 0 & 0 & 0 & 0 \\
\hline Palestinian civilian actors & 6 & $6.67 \%$ & 280 & $8.42 \%$ & 9 & $10.00 \%$ & 374 & $11.24 \%$ & 15 & $16.67 \%$ & 654 & $19.66 \%$ \\
\hline UN actors & 7 & $7.78 \%$ & 286 & $8.60 \%$ & 6 & $6.67 \%$ & 184 & $5.53 \%$ & 13 & $14.44 \%$ & 470 & $14.13 \%$ \\
\hline US political actors & 8 & $8.89 \%$ & 296 & $8.90 \%$ & 2 & $2.22 \%$ & 49 & $1.47 \%$ & 10 & $11.11 \%$ & 345 & $10.37 \%$ \\
\hline UK political actors & 0 & 0 & 0 & 0 & 2 & $2.22 \%$ & 83 & $2.50 \%$ & 2 & $2.22 \%$ & 83 & $2.50 \%$ \\
\hline International actors & 3 & $3.33 \%$ & 161 & $4.84 \%$ & 3 & $3.33 \%$ & 73 & $2.19 \%$ & 6 & $6.67 \%$ & 234 & $7.04 \%$ \\
\hline Arab political actors & 1 & $1.11 \%$ & 60 & $1.80 \%$ & 0 & 0 & 0 & 0 & 1 & $1.11 \%$ & 60 & $1.80 \%$ \\
\hline Total & 50 & $55.56 \%$ & 2035 & $61.18 \%$ & 40 & $44.45 \%$ & 1291 & $38.80 \%$ & 90 & $100.0 \%$ & 3326 & $100.0 \%$ \\
\hline \multicolumn{13}{|l|}{ The New York Times } \\
\hline Israeli political actors & 5 & $6.85 \%$ & 254 & $8.37 \%$ & 4 & $5.48 \%$ & 167 & $5.50 \%$ & 9 & $12.33 \%$ & 421 & $13.87 \%$ \\
\hline Israeli Military actors & 7 & $9.59 \%$ & 401 & $13.21 \%$ & 9 & $12.33 \%$ & 299 & $9.85 \%$ & 16 & $21.92 \%$ & 700 & $23.06 \%$ \\
\hline
\end{tabular}




\begin{tabular}{|c|c|c|c|c|c|c|c|c|c|c|c|c|}
\hline Israeli civilian actors & 2 & $2.74 \%$ & 95 & $3.13 \%$ & 2 & $2.74 \%$ & 54 & $1.78 \%$ & 4 & $5.48 \%$ & 149 & $4.91 \%$ \\
\hline Palestinian political actors & 4 & $5.48 \%$ & 132 & $4.35 \%$ & 12 & $16.44 \%$ & 388 & $12.78 \%$ & 16 & $21.92 \%$ & 520 & $17.13 \%$ \\
\hline Palestinian military actors & 0 & 0 & 0 & 0 & 0 & 0 & 0 & 0 & 0 & 0 & 0 & 0 \\
\hline Palestinian civilian actors & 15 & $20.55 \%$ & 603 & $19.86 \%$ & 4 & $5.48 \%$ & 161 & $5.30 \%$ & 19 & $26.03 \%$ & 764 & $25.16 \%$ \\
\hline UN actors & 1 & $1.37 \%$ & 47 & $1.55 \%$ & 0 & $0.00 \%$ & 0 & 0 & 1 & $1.37 \%$ & 47 & $1.55 \%$ \\
\hline US political actors & 2 & $2.74 \%$ & 112 & $3.69 \%$ & 1 & $1.37 \%$ & 54 & $1.78 \%$ & 3 & $4.11 \%$ & 166 & $5.47 \%$ \\
\hline UK political actors & 1 & $1.37 \%$ & 45 & $1.48 \%$ & 0 & 0 & 0 & 0 & 1 & $1.37 \%$ & 45 & $1.48 \%$ \\
\hline International political actors & 0 & 0 & 0 & 0 & 1 & $1.37 \%$ & 18 & $0.59 \%$ & 1 & $1.37 \%$ & 18 & $0.59 \%$ \\
\hline Arab political actors & 3 & $4.11 \%$ & 203 & $6.69 \%$ & 0 & 0 & 0 & 0 & 3 & $4.11 \%$ & 203 & $6.69 \%$ \\
\hline Total & 40 & $54.80 \%$ & 1892 & $62.33 \%$ & 33 & $45.21 \%$ & 1141 & $37.58 \%$ & 73 & $100 \%$ & 3033 & $100 \%$ \\
\hline \multicolumn{13}{|l|}{ The Jordan Times } \\
\hline Israeli political actors & 0 & 0 & 0 & 0 & 6 & $12.50 \%$ & 157 & $9.73 \%$ & 6 & $12.50 \%$ & 157 & $9.73 \%$ \\
\hline Israeli Military actors & 2 & $4.17 \%$ & 76 & $4.71 \%$ & 8 & $16.67 \%$ & 223 & $13.82 \%$ & 10 & $20.83 \%$ & 299 & $18.53 \%$ \\
\hline Israeli civilian actors & 0 & 0 & 0 & 0 & 0 & 0 & 0 & 0 & 0 & 0 & 0 & 0 \\
\hline Palestinian political actors & 4 & $8.33 \%$ & 163 & $10.10 \%$ & 8 & $16.67 \%$ & 229 & $14.19 \%$ & 12 & $25.00 \%$ & 392 & $24.29 \%$ \\
\hline Palestinian military actors & 0 & 0 & 0 & 0 & 0 & 0 & 0 & 0 & 0 & 0 & 0 & 0 \\
\hline Palestinian civilian actors & 7 & $14.58 \%$ & 278 & $17.22 \%$ & 7 & $14.58 \%$ & 261 & $16.17 \%$ & 14 & $29.17 \%$ & 539 & $33.40 \%$ \\
\hline UN actors & 1 & $2.08 \%$ & 44 & $2.73 \%$ & 3 & $6.25 \%$ & 100 & $6.20 \%$ & 4 & $8.33 \%$ & 144 & $8.92 \%$ \\
\hline US political actors & 0 & 0 & 0 & 0 & 0 & 0 & 0 & 0 & 0 & 0 & 0 & 0 \\
\hline UK political actors & 0 & 0 & 0 & 0 & 0 & 0 & 0 & 0 & 0 & 0 & 0 & 0 \\
\hline International political actors & 1 & $2.08 \%$ & 62 & $3.84 \%$ & 0 & 0 & 0 & 0 & 1 & $2.08 \%$ & 62 & $3.84 \%$ \\
\hline Arab political actors & 0 & 0 & 0 & 0 & 1 & $2.08 \%$ & 21 & $1.30 \%$ & 1 & $2.08 \%$ & 21 & $1.30 \%$ \\
\hline Total & 15 & $31.24 \%$ & 623 & $38.60 \%$ & 33 & $68.75 \%$ & 991 & $61.41 \%$ & 48 & $100 \%$ & 1614 & $100 \%$ \\
\hline \multicolumn{13}{|l|}{ Haaretz } \\
\hline Israeli political actors & 0 & 0 & 0 & 0 & 1 & $2.38 \%$ & 42 & $2.62 \%$ & 1 & $2.38 \%$ & 42 & $2.62 \%$ \\
\hline Israeli Military actors & 5 & $11.90 \%$ & 316 & $19.71 \%$ & 6 & $14.29 \%$ & 221 & $13.79 \%$ & 11 & $26.19 \%$ & 537 & $33.50 \%$ \\
\hline Israeli civilian actors & 1 & $2.38 \%$ & 57 & $3.56 \%$ & 1 & $2.38 \%$ & 24 & $1.50 \%$ & 2 & $4.76 \%$ & 81 & $5.05 \%$ \\
\hline Palestinian political actors & 4 & $9.52 \%$ & 121 & $7.55 \%$ & 3 & $7.14 \%$ & 85 & $5.30 \%$ & 7 & $16.67 \%$ & 206 & $12.85 \%$ \\
\hline Palestinian military actors & 0 & 0 & 0 & 0 & 0 & 0 & 0 & 0 & 0 & 0 & 0 & 0 \\
\hline Palestinian civilian actors & 1 & $2.38 \%$ & 75 & $4.68 \%$ & 2 & $4.76 \%$ & 36 & $2.25 \%$ & 3 & $7.14 \%$ & 111 & $6.92 \%$ \\
\hline UN actors & 6 & $14.29 \%$ & 199 & $12.41 \%$ & 1 & $2.38 \%$ & 33 & $2.06 \%$ & 7 & $16.67 \%$ & 232 & $14.47 \%$ \\
\hline US political actors & 0 & 0 & 0 & 0 & 0 & 0 & 0 & 0 & 0 & 0 & 0 & 0 \\
\hline UK political actors & 0 & 0 & 0 & 0 & 1 & $2.38 \%$ & 42 & $2.62 \%$ & 1 & $2.38 \%$ & 42 & $2.62 \%$ \\
\hline International political actors & 4 & $9.52 \%$ & 150 & $9.36 \%$ & 2 & $4.76 \%$ & 79 & $4.93 \%$ & 6 & $14.29 \%$ & 229 & $14.29 \%$ \\
\hline Arab political actors & 3 & $7.14 \%$ & 95 & $5.93 \%$ & 1 & $2.38 \%$ & 22 & $1.37 \%$ & 4 & $9.52 \%$ & 117 & $7.30 \%$ \\
\hline Total & 24 & $57.13 \%$ & 1013 & $63.20 \%$ & 18 & $42.85 \%$ & 584 & $36.44 \%$ & 42 & $100 \%$ & 1597 & $100 \%$ \\
\hline
\end{tabular}

\subsection{Themes and Reporting Expressions of Social Actors}

\subsubsection{Themes and Reporting Expressions of Political Actors}

All newspapers have labeled Israeli political actors group with official titles that signifies factuality and authority, Ex. [prime minister, minister, spokesperson, ambassador...]. The JT 
however once used a quote with an adverbial (with US backing) that indicates US leniency although it plays the main role in mediating the Israeli- Palestinian peace process, Ex.1.

Examples

1. [Israel, with US backing, claims Hamas is behind the protests, deliberately provoking violence (JT18-MAY17-NS 608)].

2. [The Palestinian Prime Minister, a senior Hamas official, leader, spokesperson, Palestinian Leader] or less formal in the case of $H Z$ [Khalil al-Hayya, a senior Hamas official, said (HZ19-OCT13-NS 1130)]

The descriptions of Palestinian political Actors were also institutional, Ex. 2. It nominated the speaker in a semi-formal way (first name family name) with a titles preceded by indefinite article [a] that indicate distance from the speaker (Fairclough 1995), compared to its formal manner with Israeli actors (Mr./Mrs. first name and family name; Mr./Mrs. family name) or their formal titles. on the other hand, whenever The NYT quoted Hamas or its people, it used negative expressions Ex. [the militant group that runs Gaza and has managed the protests, which has largely assumed responsibility for organizing the protests, The Islamic group, which is classified by much of the Western world as a terrorist organization which quickly adopted the return campaign, played a large role in orchestrating it, a Hamas representative on the organizing committee for the demonstrations, the group's leader]. These descriptions alienate the newspaper from what is said. The implied negative descriptions of the speakers in these quotes disqualify the authenticity of what is said. From CDA stand point, they illustrate the source referred to by the newspaper as unreliable or out of group.

The analysis of reporting themes and reporting verbs for Political actors shows that the Israeli political actors were quoted mainly in one theme, namely: evading responsibility of casualties. The Palestinian Political Actors, on the other hand, have the themes of criticism of the killing, reporting casualties and supporting protests. The $G U$ has neutrally reported the Israeli and Palestinian political actors with verbs like say, said, told. These neutral verbs indicate the fair practices of reporting by The GU. The NYT used favorable reporting verbs like reported, ruled out that imply a favorable stance to the source they used, Ex. 3. Such verbs can imply at least some truth in what is said or as they are biased towards the speaker than neutral say or tell. This can be also noted while sourcing the Palestinian political actors for using verbs like insisted, accused, or denounced, Ex.4. Such verbs denote conflicting and argumentative rhetorical meanings in themes related to criticizing Israel, the Palestinian leadership. The reporting verbs [accused, denounced] used by the NYT also point out to the rift in the Palestinian-Palestinian relationship between Gaza and Palestinian government. The $J T$ used less favorable quoting verbs for the Israeli Political Actors in evading responsibility of casualties with reporting expressions like claim, argue that have slightly less favorable stance to the speaker, Ex. 5, which can be directly compared to a neutral quote by the GU in Ex. 6. $H Z$ on the other hand has used neutral reporting verbs for both parties regardless of the themes they were sourced in. 
Examples

3. [Israel's defense minister, Avigdor Lieberman, ruled out participation in any commission of inquiry, telling Army Radio on Sunday that the Israeli military "did what had to be done." He added, "I think that all of our troops deserve a medal." (NYT18-APRO1-NS 1296)].

4. [Hamas, which has largely assumed responsibility for organizing the protests that began last Friday, insisted it would ensure that demonstrators at the next round were unarmed. But it said it would not deter them from throwing rocks at Israeli forces (NYT18-APR05-NS 1225)].

5. [Israel, with US backing, claims Hamas is behind the protests, deliberately provoking violence. Hamas says the demonstrations are a popular outpouring of anger, and Israel carried out a "massacre" in response. (JT18-MAY17-NS 608)].

6. [Benjamin Netanyahu, joined the US in blaming Hamas for the deaths at the border. He defended his country's use of force, saying: "Every country has the obligation to defend its borders." (GU18-MAY15-NS 894)]

\subsubsection{Themes and Reporting Expressions of Military Actors}

The GU, The NYT and $H Z$ described the Israeli military actors (IMA) by mainly using their institutional or professional titles, Ex. [military ranks, an Israeli military spokesman, Southern Command chief, The IDF spokesman, Brig. Gen. the army spokesman, ...] which signify authority. The JT used out of group description [Israeli occupation forces] in Ex. (7) that entails the violent nature of the speaker. Also, its use of [Israeli occupation forces] in a genericised term of IMA denotes negative stance of the newspaper. When newspapers nominated the Israeli military actors, they avoided vagueness and added authenticity to what was said (Floyd 2000, Halliday 2007).

Examples

7. [Early on Thursday, Israeli aircraft hit four Hamas targets in the northern Gaza Strip in response to heavy machine gun fire that struck houses in the Israeli town of Sderot, Israeli occupation forces said(JT18-MAY17-NS 608)]

Evade responsibility of casualties was the soul theme used while reporting Israeli military actors. The $G U$ used neutral reporting verbs like [said] while The NYT patterns established authority by using verbs like insists, reported, described that establish truthfulness of what is said, Ex. (8 and 9). The JT, however, used the verb alleges that imply the out of group position of the quoted speaker, Ex10. Meanwhile, $H Z$ used neutral verbs like told, said and promised. but used the verb rejected to reassure the position of the speaker of previously mentioned facts in the discourse, summarizes and reflects on what was actually happened or said (Floyd 2000). 
Examples

8. [But Lt. Col. Jonathan Conricus, an army spokesman, said its rules of engagement had not changed (NYT18-APR13-ED 1248)].

9. [Brig. Gen. Ronen Manelis, the chief army spokesman, described that as "nonsense" in an interview on Sunday, saying the number of live fire injuries was more likely in the dozens, with the rest hit by rubber bullets or tear gas.(NYT18-APR01-NS 1296)].

10. [ It also alleges there were efforts to damage the fortified fence cutting off the blockaded Gaza Strip and to infiltrate Israel. (JT18-APR02-NS 590)].

11. [Lt. Col. Jonathan Conricus, an Israeli military spokesman, rejected international criticism that Israel's response has been excessive. "snipers rifles against hundreds or thousands of rioters that are violently trying to get into Israel with the open aim of killing Israeli civilians or abducting Israeli soldiers.(HZ18-DECO9-NS 925)].

4.2.3 Themes and Reporting Expressions of Israeli and Palestinian Civilian Actors

The used Israeli civilian actors (ICA) received professional descriptions by The GU, The NYT and HZ, Ex.[ one of the founders of Breaking the Silence, an anti-occupation Israeli human rights group, an Israeli left-wing party]. These choices include genericised terms [an, one] with indefinite articles in which such genericisations in direct quotes imply a distance between the author and the taken quotes (Fairclough 1995).

The Palestinian civilian actors (IPA) received a variety of description expressions based on the nature of the themes they were quote in. for example, in the themes of circumstances of Gazan people and supporting protests, The $G U$ used professional titles like [a political scientist $]$ to describe the nature of the protests. It also used a widow that spoke about her late husband. A similar pattern is also used in the NYT with actors description like [director of PalThink for Strategic Studies, a Gazan social-media activist, a 26-year-old activist due in court this week on criminal charges for criticizing Hamas online] were used to describe the goal and nature of the protests, and in the theme criticizing the killings, it described the people by their age or relations to lost ones. A professional speaker [ a science teacher from Gaza] was quoted in the theme circumstances of Gazan people. Such choice establishes the idea of the suffering caused by the Israeli occupation and its 12 year siege on Gaza specifically. The genericised terms with zero [director], or with indefinite articles [ a science teacher] in direct quotes imply a distance between the journalist and the speaker's direct quotation (Fairclough 1995). The JT followed a similar path. For example, in the theme supporting the protests it used age or employment status to describe the speakers, [the unemployed father of four, age, relation to lost ones]. But it used professional voices in criticizing the killings [a Gaza photographer, a reporter who has worked for AFP in Gaza since 2000]. Such choices of quoting professionals emphasize the idea of the unjustified Israeli attacks on protesters. $H Z$, in its only description of Palestinian civilian actors used age description and professional background with indefinite article in the theme instigating deadly protests which implies generalized nature of all protesters and the risk they pose to Israeli soldiers on the opposite side of the fence. 
The Israeli civilian actors have two constant themes in The GU and The NYT, namely criticism of killings and evading criticism of the killings. $H Z$ quoted this group only in one theme, criticism of killings, All three newspapers used neutral reporting expressions. The Palestinian civilian actors on the other hand were assigned quotations in a variety of themes. The $G U$ reporting verbs of Palestinian civilian actors were [mourn, talking, said] when discussing the theme of supporting the protests, e.g12. Its use of verb [mourn] carries sympathy. In other themes, Ex. circumstances of Gazan people, reporting protests casualties, the social actors were assigned neutral quoting verbs. The NYT have the most distribution of themes for Palestinian civilian actors, these are circumstances of Gazan people, reporting protests casualties, supporting the protests, instigating deadly protests, actions on the ground, criticism of the killings. The NYT used neutral reporting verbs in most of them, but some reporting verbs carry paralinguistic features like yelled, shouted back, said sarcastically which carry a behavior with their communicated meaning, Ex.13, 14. The JT, with its varied themes distribution, Ex. circumstances of Gazan people, reporting protests casualties, supporting the protests, actions on the ground, criticism of the killings, used neutral reporting verbs in all themes. $H Z$ have fewer themes with Palestinian civilian actors as sources, Ex. circumstances of Gazan people, supporting the protests and instigating deadly protests, in which it used neutral reporting expressions. The $N Y T$ and $H Z$ have uniquely assigned Palestinian actors with quotations in the theme instigating deadly protests, e.g 15, 16. The use of this theme along with other journalistic practices introduced earlier overarch the idea that Palestinian casualties are mainly caused by the actions made by the protesters and that Hamas group shares responsibility since Hamas organized the protests, thus giving credit again to what Israeli actors said in their quotes.

Examples

12. ['She prayed she would be martyred': Gaza parents mourn their dead (GU18MAY20-NS 992)].

13. ["It's beautiful that we find Hamas adopting this nonviolent struggle," Mohammad Al Taluli, a 26-year-old activist due in court this week on criminal charges for criticizing Hamas online, said sarcastically.(NYT18-apr15-ED 1322)].

14. [Mr. Gerim, well within range, and resting between slinging stones, shouts back: "We want to return!']. [ a group of young Palestinian women stepped forward, in dark cloaks and colorful sneakers, gesticulating wildly. "This is our land, not yours!" yelled one. (NYT18-MA13-NS 1431)].

15. [Abdallah al-Qatati, 20, was a volunteer paramedic: "As on every Friday, I go to the border, but this Friday is different .... What is important to us is our land and our dignity. And in short, we are fleeing unto death. In the hope that the second death will be more merciful than the first. And that's the end of the story"(HZ18-AUG13-ED 1140)].

16. [young men piled tires high at protest camps along the fence, or huddled in tents where they showed off their skills in making kite-bombs, crude devices designed to destroy crops, they said. (NYT18-MA13-NS 1431)]. 


\section{Discussion}

The quantitative analysis of quotation patterns indicates higher percentages and word length of Israeli groups' quotations over Palestinian counterparts within the first part of this study signal procedural biases made by western media and by $H Z$. Even when the NYT allocated more quotations to the Palestinian political actors, it has allocated equal space for Israeli political actors' quotations. The JT has proven to reproduce the Palestinian actors favorably by assigning more quotations and word length to their sources. This finding comes especially in line with (Dunsky 2008) who found biases in space allocation towards Israel and (Zelizer, Park \& Gudelunas 2002) who found that the frequency of reporting and length of reports were "conservative in handling the details of Israeli army treatment of Arabs", a polite description of the bias they found towards Israel. The found one party narrative in the $J T$ comes in line with Bazzi (2009) findings illustrating Arab newspapers unique lexicalization and framing of the Palestinian and Israeli actors. these finding comes against (Deprez \& Raeymaeckers 2010) findings although they used national Flemish sample, but their second attempt (2011) found that some newspapers favoured the Israeli side by (the use of sources) while others opted the Palestinian side in (Ex. the individualization of victims). In their analysis of 14 newspapers across Europe, Segev and Miesch (2011) found that UK newspapers were the most critical of Israeli actions, which contradicts the findings of (Deprez \& Raeymaeckers 2010) but in line with their second study (2011).

The themes in which the social actors were assigned quotations varied as the Israeli political and military actors were mainly cited in evading responsibility of casualties and the Israeli civilian actor have the themes criticizing the killings and supporting the Israeli measures. The Palestinian political actors were mainly assigned quotations in the themes criticizing the killings, reporting casualties, supporting the protests, and instigating deadly protests while the Palestinian civilian group were assigned circumstances of Gazan, criticizing the killings, supporting the protests, instigating deadly protests. The themes in which other actors were quoted varied according to the speakers' positions. US political actors were cited in Supporting Israel while other actors have called for restraint and finding a solution. This comes in line with (Amer 2015, Philo and Berry 2004 and 2011) findings that it is easy to criticize the weak party of a conflict rather than facing consequences of criticizing Israel. The analysis of the themes echoes that notion of (Deprez \& Raeymaeckers 2011) (Amer 2015) (Qawariq 2016) (Farrah 2018) in the representations found by the $G U$ and the NYT where they quoted civilian sufferings but also included Israeli voices in defending their actions.

The analysis of the reporting expression of social actors reveals the tendency of NYT and HZ to present Israeli actors in a favorable manner. This is evident in the use of nominations, professional titles and office of the speakers that leads them be easily identified (Strauss and Feiz 2012:99). The Palestinian actors, on the other hand, received less than formal titles and were mostly generecised with indefinite articles. The NYT and $H Z$ accused Hamas militant of orchestrating the Gaza Marches of Return while providing negative images of the situation on the ground. The Palestinians, on the other hand, were given less space and neutrality when expressing their narrative. This leads to the understanding that the $N Y T$ and $H Z$ still follow the same narrative strategy of de-contextualizing the events while presenting them as 
irrelative events of conflicts to the reader's eye. On a parallel strategy, the NYT simply blamed Hamas for orchestrating the protests according to its descriptions of Palestinian political sources.

Richardson (2007) and van Dijk (1988) highlighted the importance of quotation analysis and journalistic practices that bring forward adopted narratives to the readers. This is done by providing affiliated social actors the space to express their thoughts, attitudes, and impressions on what is going on the ground. When elites are quoted in newspapers, they usually represent factual and authoritative input (Turner and Ibáñez and Grattan 2019), but this practice reproduces the elites dominant ideologies more than other less privileged groups. All newspapers have labeled Israeli political actors group with official titles that signifies factuality and authority.

\section{Conclusion}

To answer the first research question, the study found quotation patterns indicative of news bias due to the higher percentages and word length of Israeli actors' quotations over Palestinian counterparts that signal procedural biases made by western media and by $H Z$. Even when the NYT allocated more quotations to Palestinian political actors, still it has allocated equal space for Israeli political actors' quotations. The JT on the other hand, has proven to reproduce the Palestinian actors favorably by assigning more quotations and word length to their sources.

To answer the second research questions, the quantitative analysis of quotations distribution in this section shows that The Guardian, $H Z$ and The JT have adopted one party narrative, which means the dominance of certain ideas, perspectives and arguments on what is happening in the protests and gave less room to the opponent group (Palestinian side in the case of HZ, GU and Israeli side in the case of the JT) to express themselves. The use of out of group reporting verbs by The JT illustrate the negative stance of the newspaper towards what was said by the Israeli Political figures. On the other hand, the distribution of quotations patterns, their reporting verbs and themes in which they were quoted identify the authority and impact of Israeli military actors in $H Z$ and The NYT. The use of specific quotations themes in $H Z$ and The NYT conveyed the Israeli actors' narrative and defense with quotations that imply hostility of Hamas or the protesters.

Further research on the role of quotations patterns, quoting expressions and word count with a different sample can draw on the representations of social actors in the news.

\section{References}

Amer, M. (2015). War reporting in the international press: a critical discourse analysis of the Gaza War of 2008-2009. Unpublished Doctoral Dissertation, University of Hamburg.

Bazzi, S. (2009). Arab news and conflict: a multidisciplinary discourse study. Philadelphia: John Benjamins Publishing Company.

Ben, B. (2018). The Guardian most trusted and The Sun least trusted online news brand, Pamco reveals. Campaign. Retrieved May 23, 2020, from 


\section{Macrothink}

International Journal of Linguistics

ISSN 1948-5425

2020, Vol. 12, No. 6

https://www.campaignlive.co.uk/article/guardian-trusted-sun-least-trusted-online-news-brand -pamco-reveals/1492881

Blackledge, A. (2005). Discourse and power in a multilingual world. Journal of Language and Politics, 10(2).

Fairclough, N. (1995). Critical discourse analysis: the critical study of language. Language in Social Life Series, London.

Fairclough, N. (2003). Analysing discourse: textual analysis for social research. London: Routledge.

Farrah, M. (2018). Discourse in a confrontational situation: the Palestinian-Israeli conflict. Language, Discourse \& Society, 6(2).

Floyd, A. (2000). The reporting verbs and Bias in the Press. Revista Alicantina de Estudios Ingleses, 13(13). https://doi.org/10.14198/raei.2000.13.04

Mihelj, S., \& Stanyer, J. (2018). Theorizing media, communication and social change: Towards a processual approach. Media, Culture and Society, 1-20.

Morris, L., \& Balousha, H. (2018). Israelis kill more than 50 Palestinians in Gaza protests, health officials say. The Washington Post.

Patton, M. Q. (2002). Qualitative research and evaluation methods (3rd ed.). Thousand Oaks, CA.

Qawariq, R. (2015). Victims vs Terrorists? The Discursive Construction of Palestinians in Two Online Israeli Newspapers during the 2014 Gaza War. Networking Knowledge, 8(2).

Richardson, J. (2007). Analysing newspapers: an approach from critical discourse analysis. Macmillan, Basingstoke.

Riofrancos, T. (2002). On both sides of the Atlantic, the signs of radical possibility are everywhere. New York Times. Retrieved August 9, 2020, from https://www.nytimes.com/2020/08/09/opinion/left-politics.html

Sanchez, R., \& Oliphant, R. (2018). Gaza braces for protests and funerals a day after at least 58 Palestinians killed by Israeli troops. The Daily Telegraph.

Seale, C. (2012). Researching society and culture. London: Sage.

Segev, E., \& Miesch, R. (2011). A Systematic Procedure for Detecting News Biases: The Case of Israel in European News Sites. International Journal of Communication, 5, 1947-1966. Retrieved February 25, 2019, from http://ijoc.org

The Center for Research Libraries (CRL). (2020). CRL Obtains Haaretz. Retrieved May 5, 2020, from www.crl.edu

The Guardian. (2019). About Us. Retrieved May 12, 2019, from theguardian.com 


\section{Macrothink}

International Journal of Linguistics

ISSN 1948-5425

2020, Vol. 12, No. 6

The Jordan Times. (1995). The Jordan times celebrate its birthday. Retrieved May 12, 2019, from thejordantimes.com

Titscher, S., \& Jenner, B. (2000). Methods of text and discourse analysis. London: Sage.

Turner, B., Ibáñez, D., \& Grattan, S. (2019). Reporting from the Wars 1850-2015: The origins and evolution of the war correspondent. Wilmington, Delaware: Vernon Press.

United Nation Development Program (UNDP). (2018). How Media Can Be an Instrument of Peace in Conflict-prone Settings. UNDPOGC Media Conflict Roundtable Background Paper.

$\begin{array}{llll}\text { Retrieved } \quad \text { May 20, from } & \text { 2020, }\end{array}$ https://www.undp.org/content/dam/norway/undp-ogc/documents/UNDPOGC_Media_conflic t\%20roundtable\%20background\%20paper.pdf

Van Dijk, T. (1995). Aims of Critical Discourse Analysis. Japanese Discourse, 1(1), 17-28.

Van Dijk, T. (1998). Ideology: A multidisciplinary approach. London: Sage.

Van Dijk, T. (2018). Discourse and Migration. In R. Zapata-Barrero, \& E. Yalaz (Eds.), Qualitative research in European migration studies. Cham: Springer.

Van Dijk, T. A. (1988). News analysis: case studies of international and national news in the press. N.J.: Hillsdale.

White, P. R. R. (2000). Media objectivity and the rhetoric of news story structure. In E. Ventola (Ed.), Discourse and community (pp. 379-397). Tübingen: Narr.

Wodak, R. (1996). Disorders of discourse. London: Longman.

Zaher, A. (2009). A critical discourse analysis of news reports on the Israeli/Palestinian conflict in selected Arab and Western newspapers. Doctoral Dissertation, Nottingham Trent University.

Zelizer, B., Park, D., \& Gudelunas, D. (2002). How bias shapes the news challenging the New York Times' status as a newspaper of record on the Middle East. Journalism, 3, 283-307.

\section{Copyrights}

Copyright for this article is retained by the author(s), with first publication rights granted to the journal.

This is an open-access article distributed under the terms and conditions of the Creative Commons Attribution license (http://creativecommons.org/licenses/by/4.0/) 